\title{
Developing Peripheral Learning Material to Improve Students' Vocabulary for The Fifth Grade of Elementary School
}

\author{
W. Saputra ${ }^{1}$, N.N. Padmadewi ${ }^{2}$, L.P. Artini ${ }^{3}$. \\ ${ }^{123}$ English Language Education, Post Graduate Program, Universitas Pendidikan Ganesha, Singaraja \\ e-mail: gus wissnow zaputrha@yahoo.com, nyoman.padmadewi@pasca.undiksha.ac.id, \\ putu.artini@pasca.undiksha.ac.id
}

This study aimed at developing peripheral learning material in an attempt to improve fifth grade students' vocabulary. This study used ADDIE model proposed by McGriff to develop the product. The stages used were (1) Analyze, (2) Design, (3) Develop, (4) Implement, and (5) Evaluation. Based on the result of need analysis it can be concluded that the peripheral learning material produced was in the form of poster that contained word, picture and simple sentence by concerning the criteria of the good material and poster. The interview guide and questionnaire were used in this stage as the instruments. After analyzing the needs, the product was design by making the blueprint, draft, illustration as well as inserting the word and sentences. The product was revised and developed in the development stage. Furthermore, the product was implemented in limited trial by attaching the poster around the class, conducting the first observation, changing the poster, and conducting the second observation. The response of the students and the teacher were gained by using the questionnaire and the interview. In order to check the quality of the product, the expert judgement sheet was used as the instrument. From both of expert judges it can be categorized that the product was excellent product.

Keywords: Peripheral learning, Poster, Vocabulary. 


\section{INTRODUCTION}

In Indonesian latest curriculum (i.e. Curriculum 2013), English is no longer a compulsory lesson. However some of elementary schools in Bali especially in Buleleng Regency are still using English as one of the additional lessons or local subject (Muatan Lokal). Based on the preliminary observation conducted by the research in several elementary schools which implemented kurikulum 2013 in Buleleng Regency, such as SDN 1 Dencarik, SDN 9 Banjar, and SDN 1 Temukus, there were some reasons of why those schools used English as one of the additional lesson or local subject (muatan lokal). As the first reason, Buleleng Regency was one of the tourism objects in Bali. This reason made English as one of the languages that everyone should know. Second, it was expected that the students can take a part in tourism's executant. Last, students should master English in order to open more chance in fining job and better future. Knowing that English was one of the important things to be taught in school, teaching vocabulary also became one of important things to be accomplished by the teacher.

Vocabulary plays an important role especially in learning English for the students. It is because vocabulary appears in every language skill. Vocabulary building is really important in any language learning. The more vocabulary that we know, the easier way that we can find to express our ideas. As mentioned by Segler in Seyed (2014) insufficient vocabulary and lexical errors may be a barrier for communicating. That is why vocabulary is really important. As stated in the Collier (1991): "Once students mastered the fundamental grammatical patterns of a language, his next task into master its vocabulary that he needs. Nobody ever learns all the words in any language. We know and use the word that suit our particular purposes and we continue to learn new words as long as we live". It is clear enough that everybody who learns a language as foreign language is hoped to know and master to improve their language skills.

Nation (2001) mentions vocabulary also will help the learner in the context of written form. In the context of reading listening, speaking or writing text if the learners have difficulties to comprehend the word it will interrupt the activity so much. Besides that, vocabulary also a continual process of encountering new words in meaningful and comprehensible contexts because one word has many meaning and vocabulary is not as simply like memorizing definitions of the word, but the learners should focus on the word use in meaningful context, Harmon, Wood and Keser. (2009). Therefore, we should comprehend the vocabulary depend on the context. Ahmad in Seyed (2014) states that learning vocabulary is an ongoing task and it is an essential part of language learning. It is also a process for language learners to achieve proficiency and to develop competency in second language (L2).

However, some of the school teachers interviewed by the researcher in the preliminary observation mentioned some obstacles in the process of teaching English and vocabulary for the fifth grade of elementary school. First, the availability of English books from where the students can learn new vocabulary in English is very limited. The material of the book was not coverage all of the material that should be taught. Second, the students only learn the vocabulary based on vocabulary list given by the teacher during the learning process. Moreover English as additional lesson or local subject (local-content curriculum) only taught once in a week so it was very likely that the new vocabulary was easily forgotten by the students. To make it worse, media to introduce vocabulary was not available in the schools observed so that students very much relied on the teachers' teaching materials. Another observation was done in two different primary schools in the same regency. In this observation the researcher found out that most of the students took a note on their own note book to write the English vocabulary given by the teacher. They only book available for the students was English Workbook (LKS) which was photocopied from the original one. Thus, it can be imagined that it was not attractive for the students since it was not colourful (i.e. black and white). Every week, when English subject was scheduled, students waited for the teacher to teach them some new English vocabulary. This was in line with the research conducted by Artini (2014) who stated that with limited resources and facilities in learning English in Indonesian schools, teachers usually become the only source of learning in the classroom, and a textbook is the only learning material. Another result of classroom observation showed that the classroom was arranged in very conventional way. There were only a white board, 
chairs, desks, cupboard and others general things in the classroom. The pictures attached in the class were only the picture of president and vice president, Indonesian hero and scenery.

Up to this point, it is not difficult to imagine that facilitation that help children improve their vocabulary in English was badly needed. Considering this problem and the potency that was found out during the observation, the researcher was intended to develop the material in order to improve the students' vocabulary based on the characteristic of the students as young learner. Teaching English for young learner should be conducted in natural ways. Young learners usually acquire language or learn subconsciously rather than learn consciously. According to Cameron \& McKay (2010), young learners are the learners at the age of 5-12 years. Meanwhile Aisyah et al (2012) states in the context of Indonesian education system, young learners here refer to primary school age students, ranged from 6 to 12 years old. In those range of age, young learners have some characteristics that should be considered by the teacher because they are different with adults. One of those characteristics is young learners are an active learner (Piaget in Cameron, 2001). As an active learner, young learners like to be involved in learning process. It is because they learn something from everything around them more indirectly than directly (Harmer, 2001). They like learning something from what they see, hear, touch, and interact with (Harmer, 2001).

According to Cameron (2001), young children can learn second language particularly effective because their brains are still able to use the mechanisms that assist first language acquisition. So that, it means that the foreign language learning will be more effective if it is started earlier because young learners are often more enthusiastic and lively as a learners. Most children are naturally curious about their surroundings. They have an interest in exploring and investigating to see how things work and why things happen. Children have an innate sense of wonder and awe a natural desire for inquiry. The nature of children wants to know and understand. In their effort to know and understand, they build their ideas about the world around them. They are remarkable for their curiosity and their intelligence. (Piaget in Cameron, 2001) also stresses that children actively construct their own cognitive worlds; information is not just poured into their minds from the environment. He sought to discover how children at different points in their development think about the world and how systematic changes in their thinking occur.

By concerning about the characteristic of young learner, the material developed was in the form of peripheral learning. Peripheral Learning was one of the techniques in suggestopedia method. Scovel (1979) mentions suggestopedia is a method developed by the Bulgarian psychiatrist educator Georgi Lozanov in 1978. Suggestopedia tries to harness these influences and redirect them so as to optimize learning. The most conspicuous characteristics of Suggestopedia are the decoration, furniture, and arrangement of the classroom, the use of music, and the authoritative behavior of the teacher.

The characteristic of Suggestopedia developed the theory of Peripheral Learning. Lozanov (1978) believes that students can learn a lot of things that they see around them. This is based upon the idea that we perceive much more in our environment than we consciously notice. It is claimed that, by putting posters containing grammatical information about the target language on the classroom walls, students will absorb the necessary facts effortlessly. The teacher may or may not call attention to the posters so the students are not assigned to study them. The purpose was to provide students with peripheral learning. They are changed from time to time to provide grammatical information that is appropriate to what the students are studying. According to McGlothlin (1997) who observed his children's first language development, a child does not use language for its own sake. In reality, he never pays attention to language by any means. For a child, language is considered a means to an end, that is, his joy. Therefore, first language acquisition in early stages is mainly peripheral. This research was focus on peripheral learning material in order to improve the vocabulary of the students.

\section{RESEARCH METHOD}

The study employed a mixed method in the form of explanatory mix method by using ADDIE model. ADDIE model was a model proposed by McGriff (2000). This study was 
conducted at fifth grade in SDN 1 Dencarik. The class elected was in the fifth grade. The developing peripheral learning material of this research used ADDIE model that included 5 steps. (1) Analyze. In this step, there were an analysis of the potency of the problem and the needs of the students. (2) Design, in this phase, the researcher designed the product that can improve the students' vocabulary. (3) Development, in this phase the expected product of the researcher started to be developed. (4) Implementation, after the development phase, the next phase was the implementation. In this phase the researcher was trying out product in the fifth grade of elementary school's students. (5) Evaluation, the evaluation was conducted by concerning the feedbacks given by the students and the teacher.

There were six methods used by the researcher in conducting this research. Those were (1) observation, (2) Document Analysis (3) Interview, (4) Expert Judgement (5) Limited field trial, and (6) distributing questionnaire. The data were collected by using some instruments such as (1) Note, (2) Interview guide, (3) Expert Judgement sheet and (4) Questionnaire. The result of every stage was described descriptively and in order to measure the quality of the product the researcher used formula proposed by Candiasa, (2010).

\section{FINDINGS AND DISCUSSION}

In this research, all of the stages in ADDIE were done by the researcher in order to produce the media. Those stages were Analyze, Design, Development, Implementation and Evaluation. First, the Analyze stage was conducted by using several techniques. Those were observation, interview, questionnaire, and document analysis. By doing those kind of analysis and by considering the need of the students, it was decided that the peripheral learning material developed in this research was peripheral learning in the form of poster that contain word, sentence and image. It was correspond based on the Diane Larsen and Freeman (2000) who state that by putting posters containing some language features and grammatical information about the target language on the classroom walls, will enable learners to absorb the necessary facts effortlessly. Besides that, poster was chosen because it brought some benefits such as motive and inspire students to learn, stimulate interest in the topic, effectively illustrate a concept or skill, provide reproducible for student use, provide directions for handson activities and provide suggestions for additional instructional activities (Osa and Musser, 2004). Moreover, posters are colorful, attractive learning media which can enhance the learning environment (Musser and Osa, 2004).

In making the poster, the researcher first of all learned the 12 characteristics of the product and the criteria of good material done by Tomlison (1998). The criteria comprise: materials should achieve impact, materials should help learners to feel at ease, materials should require and facilitate learner self-investment, the learners' attention should be drawn to linguistic features of the input, and materials should provide the learners with opportunities to use the target language to achieve communicative purposes. From those criteria of the good material the characteristic of the poster was developed. The criteria were: the media developed was in the form of Vocabulary material. the media was in the form of poster, the media contained picture based on the vocabulary introduced, the media contains "English words" and "English structure in a sentence", the sentence used in the media was a simple sentence, the picture, word and sentence were clear and understood at a glance, the poster was structured, the media was colorful and interesting, the poster was observable, the size of the poster is using A2 paper: $420 \times 594 \mathrm{~mm}$, the number of posters attached in the classroom were 15-20 posters, and the poster produced in 3 different themes.

Second, in designing the poster the researcher was taking some steps. Those were by making blueprint of the media designed based on the data from syllabus analysis and the result of the need's analyses. Making the draft of peripheral learning material that was developed as well as making illustration, inserting word and sentences and finally the early final designs produced in each theme. The poster was made based on the criteria of the good poster proposed by O'Neill. G \& Jennings. D (2012). The criteria of the good poster consist of the message, the design, the accessibility and awareness as well as the production. 
Third, the development was done by using two expert judges who judged and gave the revision as well as the suggestion to the researcher. There was only one revision given from the whole of the product. All of the design of the product became the final product and ready to be implemented.

Fourth, the implementation was done after the development of the product. It was done by doing the short time implementation that was conducted around three weeks. In the first week, the researcher attached 12 posters in the class before the theme was introduced by the teacher. In the next meeting the first observation was done. The result was very good. The students were actively involved in mentioning the English word as well as in the speaking activity. The students were really independent in knowing the word as well as increasing their motivation in learning. In order to checking the progress of the students, the researcher continued the implementation by changing the posters into the new vocabularies introduced but still in the same theme. This was exactly what had been proposed by the Diane Larsen and Freeman (2000) that in applying the peripheral learning, the material should change time to time to provide language information that is appropriate to what the students were studying.

After changing the poster in the previous week, the second observation was done by the researcher. In the second observation, the students was actively involved in mentioning the vocabulary introduced by using the picture without word as well as practiced speaking by using the simple sentence. The students had a good progress in achieving vocabulary as the posters attached in the classroom. Besides that the researcher received good feedback from the students and the teacher. The students felt that they really interested to the posters attached around the class as well as it helped them to learn English and improving their vocabulary acquisition. Besides that the posters also assisted them to develop their reading, speaking, and writing skill. They became more independent. This was in accordance with Padamadewi (2016) who stated that being self-directed in learning is the skill that most students need to achieve and most teachers are aware of how important it is to lead students to be self-directed and by peripheral learning this can be accomplished. From the teacher side, the poster really helps her to teach English. The teacher felt that the students were more independent in learning and could involve a lot during the class. This good result was connected to the previous research done by Bahmani, Pazhakh, and Sharif (2012). The result proved that the ability of learners' self-learning must be taken into account can enhance the autonomy and confidence and as a result motivation in students.

The evaluation stages were conducted in every stage of ADDIE model and in the end of the model. There were some evaluations proposed in order to make a good product. In the evaluation, the researcher found out that the students were really interested in the product that can help them to gain more English vocabulary as well as developing their language skill. The teacher also gave positive evaluation toward the product that helped her in teaching English to be easier. Both of the teacher and the students stated that the product was already in good quality. Another evaluation came from the expert judges and supervisors toward every process done in ADDIE model.

In order to know the quality of the big book, the result of expert judgment, student's questionnaire and teacher's interview during trying-out was used. Based on those result, it could be concluded that the quality of the big book developed was categorized as excellent media. The quality of the product the researcher was measured by formula proposed by Candiasa, (2010).

The researcher also gained the comments toward the strength and weaknesses from the expert judges. From the expert judges it was proposed some strengths such as: the product was really interesting in the form of the design, the size is readable for the students, the message was easily to be caught by the students and the production of the poster was also good. However, there were some weaknesses as well as advice given the expert judges. First, for some design such as rain and rainy poster the message was confusing. It was because the translations of those were quite similar in Bahasa Indonesia. Second, from the frozen poster the message might be misunderstood due to the design given. Last from the seasons poster, it might be misunderstood because it was not used in real life environment so it may lead 
misinterpret among the reader. It was suggested to the researcher to keep making a bright and interesting poster with a clear design, so the students were happy to learn.

\section{CONCLUSION AND SUGGESTIONS}

According to the finding and discussion in the previous chapter, the present study can be concluded as follows:

(1) In order to develop the peripheral learning material this research used mix method in the form of explanatory mix method by using ADDIE model. ADDIE model is a model proposed by McGriff (2000). There were five stages in this research. Those were Analyze, Design, Development, Implementation and Evaluation. First, the Analyze stage was conducted by using several techniques. Those were by doing observation, interview, questionnaire, and document analysis.

(2) In the design stage the researcher was taking some steps by making blueprint of the media, making the draft of peripheral learning material, inserting word and sentences and finally the early final designs produced in each themes.

(3) The development was done by using two expert judges who judged and gave the revision as well as the suggestion to the researcher. Fourth, the implementation stage was done by attaching the poster, doing the first observation, changing the poster, and doing the second observation.

(4) The evaluation stage done by giving the students questionnaire and whole class interview as well as conducting interview with the teacher.

Based on the findings described above, it can be concluded that kind of peripheral learning produced to improve the students' vocabulary of the fifth grade of SDN 1 Dencarik was in the form of poster. In order to make the peripheral learning in the form of poster, there were 12 characteristics proposed as the result of the analyze stage. In order to know the quality of the big book, the result of expert judgment, student's questionnaire and teacher's interview during trying-out was used. Based on those result, it could be concluded that the quality of the developed media was categorized as excellent media. The quality was completed by adding some strength, weaknesses, and suggestion.

It is suggested to make creative steps of teaching. The peripheral learning material was the supportive learning material attached around the classroom where the students can learn independently from their surroundings. The teacher should be so creative in bridging between the materials that going to be introduced and the background knowledge that the students got by reading the poster around the class. It is expected for the teacher to use the background knowledge of the students and develop it the process of learning. The students should use the vocabulary as well as practiced speaking in the class. For the students it is suggested to be more aware to the things around the class. Peripheral learning is really good to develop their independency in learning as well as to develop their literacy by reading. By poster around the classroom premises, it can be expected that students had positive exposures to new English vocabulary around them.

Since this research was conducted in limited time of implementation, there are some parts which may need to be improved. For other researchers who have intention to do similar study, it is suggested to spend more time on the implementation stage where the researcher can change the poster from time to time by using more than one theme. Furthermore, the researchers have to involve the teacher in every stage of the implementation as well as by giving the clear picture of how the steps of technique.

\section{REFERENCES}

Aisyah et al (2012). Perkembangan dan Konsep Dasar Pengembangan Anak Usia Dini. Banten: Universitas Terbuka. 
Artini, L.P.,(2014) 'Establishing Rich Language Learning Environment at Schools: Preparing Children to Become Autonomous EFL Learners. SULE-International Conference, Mei 2014 (Palembang, Indonesia)

Bahmani. M. Pazhakh, A. and Raeesharif, M. (2012). The effect of peripheral learning on vocabulary acquisition, retention and recall among Iranian EFL learners. Higher Education of Social Science, 3(1), 44-52.

Cameron, L and McKay, P (2010) Bringing Creative Teaching into Young Learner Clssroom. Oxford: Oxford University Press

Collier (1991) Macmillan International, A Division of The Macmillan Company, The Key to the English Vocabulary. London: the Macmillan Company. p.189

Freeman, Diane. (2000). Techniques and Principles in Language Teaching. (2.ed.). Oxford, The United Kingdom: Oxford University Press.

Harmon, J. M., Wood, K. D., \& Kiser, K. (2009). Promoting lvocabulary learning with the interactive word wall. Middle School Journal, 40(3), 58-63.

Harmer, J. (1991). The Practice Of English Language Teaching (1.ed.). Essex, England: Pearson Education Limited.

Harmer, J. (2001). The Practice Of English Language Teaching (3.ed.). Essex, England: Pearson Education Limited.

Lozanov, G. (1978). Suggestology and outlines of suggestodedy. London: Gordon and Breach Science Publishers, Inc.

Nation, I.S.P. (2001). Learning Vocabulary in Another Language. Cambridge: Press. 
Osa, O.J.,Musser, R.L.,(2004). The Role of Posters in Teacher Education Programs. Education Libraries Volume 27, No. 1 Summer 2004. Pennsylvania State University.

O'Neill. G \& Jennings. D.,(2012). Assesment : The Use of Posters for Assessment: A Guide for Staff. Ucd Teaching and Learning/ Resources. Retrieved from http://www.ucd.ie/t4cms/UCDTLA0039.pdf

Padmadewi, N.N. 2016. Techniques of Promoting Autonomous Learning in the Classroom. Journal of Education and Social Sciences, Vol. 3.

Scovel, T. (1979). Review of suggestology and outline of suggestopedy. TESOL, Quarterly 13: 255-66

Seyed, JAR (2014). Does Peripheral Learning Improve EFL Learners' Spelling? International Journal of Language and Linguistics. Vol. 2, No. 2, 2014, pp. 62-67. doi: 10.11648/j.jill.20140202.13

Tomlinson, B. 1998. Materials Development in Language Teaching. Cambridge: Cambridge University Press. 